\title{
Seasonal activity of Coleoptera attracted by fermental crown traps in forest ecosystems of Central Russia
}

\author{
Alexander B. Ruchin ${ }^{1 *}$, Leonid V. Egorov ${ }^{1,2}$, Anatoliy A. Khapugin ${ }^{1,3}$ \\ ${ }^{1}$ Joint Directorate of the Mordovia State Nature Reserve and National Park “Smolny”, Russia; \\ "e-mail: ruchin.alexander@gmail.com \\ ${ }^{2}$ State Nature Reserve "Prisursky", Russia \\ ${ }^{3}$ Tyumen State University, Russia
}

Received: 27 January 2020 / Accepted: 28 April 2020

\begin{abstract}
The seasonal activity of Coleoptera was studied using fermental crown traps. The study was conducted from April to October 2019 in five forest biotopes (aspen, lime, pine, birch and oak) in the territory of the Mordovia State Nature Reserve (Russia, Republic of Mordovia). Eighty-three species are found from 31 families. Cerambycidae (13 species), Nitidulidae (11 species) and Curculionidae (9 species) had the greatest species diversity. A significant part of the identified taxa (57 species from 23 families) can be attributed to saproxylic beetles. The peak abundance of Coleoptera in four biotopes (aspen, lime, pine and birch forests) was in mid-May; in an oak forest, it was at the beginning of June. Seven species seasonal activity was monitored (Cryptarcha strigata, Glischrochilus hortensis, Glischrochilus grandis, Cychramus luteus, Soronia grisea, Protaetia marmorata and Anisandrus dispar).
\end{abstract}

Key words: Coleoptera, seasonal dynamics, fermental crown traps, species diversity.

\section{Introduction}

In the temperate zone, periods of annual seasonal changes in the organisms' lives often correlate with environmental changes, especially with temperature ones. Therefore, animal species from high latitudes are most sensitive to climate and have the most phylogenetically preserved phenological phases (Samach \& Coupland, 2000; Pau et al., 2011). According to Parmesan (2006), Visser et al. (2010), Pospelova et al. (2017), global climate change, including an increase in average temperatures, leads to noticeable shifts in phenology and to large differences in this regard between species as well. Pau et al. (2011) suggested that species from temperate latitudes will respond to climate change through time-shift. Changes in organisms and populations in response to climate change can lead to a variety of consequences, including seasonal cycle mismatches (Memmott et al., 2007; Post \& Forchhammer, 2008; Singer \& Parmesan, 2010; McCauley et al., 2015; Sawoniewicz, 2015). Thus, the seasonal aspects of species biology are key processes that can link climate change with population conservation and community composition (MillerRushing et al., 2010).

The seasonal cycles of Coleoptera activity have been studied for a long time and in various ways. A large number of studies describe in detail the seasonal activity of species such as 
Carabidae (Pozsgai \& Littlewood, 2014; Kašák et al., 2017; Ruchin et al., 2019b; Zamotajlov et al., 2019), Staphylinidae (Levesque \& Levesque, 1996; Nasir et al., 2012), Scarabaeidae (Negrobov, 2009; Subchev et al., 2011), Cerambycidae (Faccoli et al., 2015; Handley et al., 2015), Elateridae (Ruchin et al., 2018), and many others. Standard methods are applied to examine them. The most often used method is the setting different types of traps (Levesque \& Levesque, 1996; Bouget et al., 2008; Trushitsyna et al., 2016; Tomaszewska et al., 2018). On the other hand, when studying the activity of some Coleoptera groups, scientists apply methods based on the use of various baits (Price, 2004; Byk \& Weggrzynowicz, 2015). Recently, we have been successfully using fermental crown traps, which have proved effective while studying some insect groups biology, including their seasonal activity (Egorov \& Ivanov, 2018; Ruchin \& Egorov, 2018; Ruchin et al., 2020). Using these traps, we studied the seasonal dynamics of Coleoptera in different biotopes and obtained the results that are presented in this article.

\section{Material and methods}

The material was collected from April 25 to October 29, 2019, in five biotopes located within the Mordovia State Nature Reserve (Russia, Republic of Mordovia, Temnikov district). In total, 4977 Coleoptera specimens were caught.

Mordovia State Nature Reserve (MSNR) with an area of $321.62 \mathrm{~km}^{2}$ is located in the northeastern part of the Oka-Don Lowland and in the southeastern part of the Oksko-Klyazma Woodland, on the wooded right bank of the Moksha River (Fig. 1). In MSNR, heights increase in the direction from southwest to northeast. The maximum elevation is in the central part and it is about $191 \mathrm{~m} \mathrm{A.} \mathrm{S.} \mathrm{L.,} \mathrm{the} \mathrm{minimum} \mathrm{is} \mathrm{about} 100 \mathrm{~m} \mathrm{A.} \mathrm{S.} \mathrm{L.} \mathrm{and} \mathrm{it} \mathrm{is} \mathrm{located} \mathrm{in} \mathrm{the} \mathrm{floodplain}$ of the Moksha River in the western part. Some sites (especially in the western half) have a special dune relief. Geobotanically, the MSNR territory is located near the southern border of the coniferous-deciduous forests subzone, and the forest is one of the most southern complexes of the southern taiga type. In general, the MSNR vegetation cover is considered taiga with a certain tendency towards the non-moral complex during successions (Khapugin et al., 2016; Ruchin \& Egorov, 2017; Ruchin \& Mikhailenko, 2018; Khapugin \& Ruchin, 2019; Ruchin et al., 2019a). 


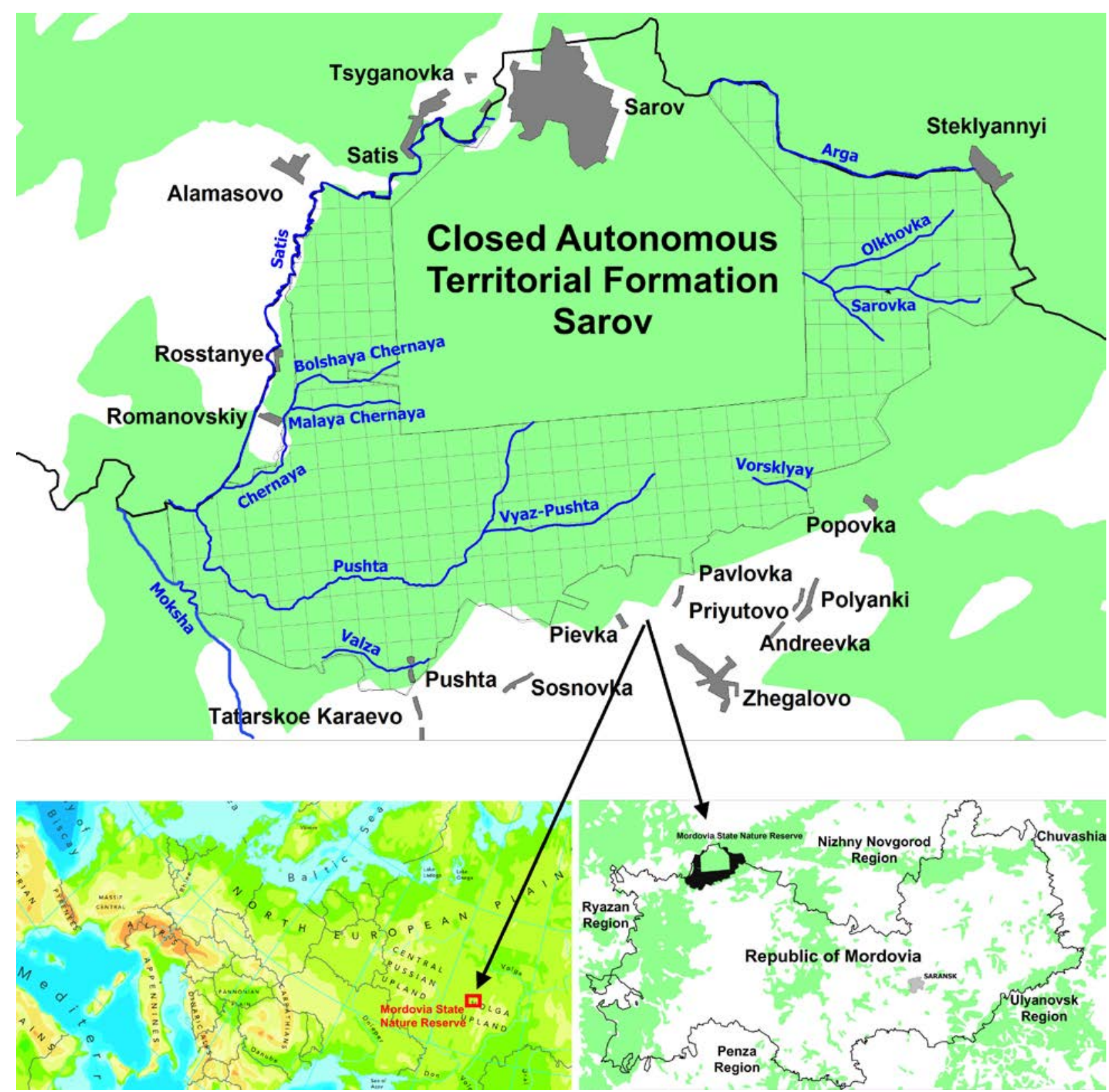

Figure 1. Mordovia State Nature Reserve, Russia location and study sites

The descriptions of the studied biotopes are given below. Each biotope was distinguished by the predominance of a particular tree species.

1) The forest area with a predominance of Pinus sylvestris (pine forest).

The habitat is a pine (Pinus sylvestris L.) forest with 100\% participation in forest stand. Second layer is well pronounced, representing by lime (Tilia cordata Mill.) with 70-80\% projective cover. Shrub layer consists of Acer platanoides L., Euonymus verrucosus Scop., Sorbus aucuparia L., saplings of Tilia cordata. Carex pilosa Scop. predominates in herb layer (projective cover is 70\%). It also includes Glechoma hederacea L., Lathyrus vernus (L.) Bernh., Rubus saxatilis L., Asarum europaeum L., Dryopteris filix-mas (L.) Schott, Vicia sylvatica L., Convallaria majalis L., Aegopodium podagraria L., Mercurialis perennis L., Pteridium aquilinum (L.) Kuhn. 
2) The forest area with a predominance of Tilia cordata (lime forest).

The first layer of forest community is formed by Tilia cordata Mill. (70\%), Betula pendula Roth (20\%), Populus tremula L. (10\%). The second layer is slightly pronounced, being formed by Tilia cordata. The shrub layer is sparse. It is formed by Acer platanoides L., Corylus avellana L., Euonymus verrucosus Scop. Herb layer is represented by Dryopteris filix-mas (L.) Schott, Glechoma hederacea L., Viola mirabilis L., Aegopodium podagraria L., Asarum europaeum L., Stellaria holostea L., Asarum europaeum L., Carex pilosa Scop., Monotropa hypopitys L., Pulmonaria obscura Dumort., Galium odoratum (L.) Scop., Lathyrus vernus (L.) Bernh., Convallaria majalis L.

3) The forest area with a predominance of Populus tremula (aspen forest).

The habitat is a deciduous forest, where first layer consists of Populus tremula L. (60\%), Tilia cordata Mill. (30\%), Betula pendula Roth (10\%). Second layer is represented by Tilia cordata, Betula pendula. Shrub layer has projective cover of 40-50\%. It includes Acer platanoides L., Tilia cordata, Corylus avellana L., Euonymus verrucosus Scop. Herb layer is represented by Dryopteris filix-mas (L.) Schott, Aegopodium podagraria L., Mercurialis perennis L., Asarum europaeum L., Lathyrus vernus (L.) Bernh., Glechoma hederacea L., Carex pilosa Scop., Rubus saxatilis L., Stachys sylvatica L., Pulmonaria obscura Dumort.

4) The forest area with a predominance of Betula pendula (birch forest).

The first layer of the forest community consisted of Betula pendula Roth (90\%) and Tilia cordata Mill. (10\%). Second layer includes Tilia cordata (25\%) with participation of Betula pendula. Shrub layer is represented has total projective cover of $40-50 \%$. It includes Acer platanoides L., Prunus padus L., Euonymus verrucosus Scop., Lonicera xylosteum L., Sorbus aucuparia L., Frangula alnus Mill., saplings of Picea abies (L.) H.Karst., Tilia cordata. Herb layer includes Dryopteris filix-mas (L.) Schott, Asarum europaeum L., Oxalis acetosella L., Pulmonaria obscura Dumort., Carex digitata L., C. pilosa Scop., Glechoma hederacea L., Lathyrus vernus (L.) Bernh., Aegopodium podagraria L., Mercurialis perennis L., Equisetum sylvaticum L., Geum urbanum L., Polygonatum multiflorum (L.) All., Stellaria holostea L.

5) The forest area with a predominance of Quercus robur (oak forest).

The habitat is floodplain forest consisted of Quercus robur L. (90\%) and Ulmus glabra Huds. (10\%). Second layer is represented by Quercus robur, Tilia cordata Mill., Betula pendula Roth, Ulmus glabra. Projective cover of shrub layer is about $50-55 \%$. It includes Prunus padus L., Acer platanoides L., Corylus avellana L., Viburnum opulus L., Rubus idaeus L., saplings of Ulmus glabra, Tilia cordata, Malus sylvestris (L.) Mill. Herb layer is represented by Mercurialis perennis L., Scrophularia nodosa L., Fallopia convolvulus (L.) Á.Löve, Geum urbanum L., Urtica dioica L., Mentha arvensis L., Glechoma hederacea L., Impatiens noli-tangere L., Festuca 
gigantea (L.) Vill., Convallaria majalis L., Carex pilosa Scop., Stellaria media (L.) Vill., Arctium lappa L., Alliaria petiolata (M.Bieb.) Cavara \& Grande, Stellaria holostea L., Campanula trachelium L.

A five-liter plastic container with a window cut out on one side at a distance of $10 \mathrm{~cm}$ from the bottom was used as a trap (Ruchin et al., 2020). In each biotope, two traps were installed under the forest canopy at a distance of five $\mathrm{m}$ from each other. Traps were hung on tree trunks in a crown seven to eight meters high. Fermented beer with added sugar was used as bait. The sampling period ranged from six to 17 days. All counts were carried out by A. Ruchin.

Coleoptera was determined by L.V. Egorov. The assignment of species to saproxyl was carried out based on our own and published data (Lachat et al., 2012; Redolfi De Zan et al., 2014). The Coleoptera system, the volume and nomenclature of taxa were predominantly taken from the "Catalogue of Palaearctic Coleoptera” (2007, 2008, 2010, 2011, 2013, 2015, 2016, 2017), the number of families and nomenclature Curculionoidea was taken from AlonsoZarazaga et al. (2017).

\subsection{Data analyses}

The calculation of the caught specimen's number to the trap exposure days number was carried out to analyze the seasonal dynamics of individual species. Uncertain species were not taken into account in the calculations for species diversity. In the grouping of similar environments based on the coleopterans families found in each one, the Jaccard similarity index was used, which considers the presence and absence of species. The UPGMA method was used to group the areas using PAST software (Hammer et al., 2001). The diversity analysis among the ecosystems was evaluated by the following diversity indexes: Shannon-Wiener $\left(\mathrm{H}^{\prime}\right)$, which consider equal weight to the rare and abundant species and Simpson's index (1-D), which is characterized by being sensitive to changes in the most abundant species composition (Peet, 1974) were employed. The uniformity among the coleopterans caught in the five sampling areas was calculated with the Berger and Parker index. This part of the study was performed by A.A. Khapugin.

\section{Results}

Eighty-three species were identified from 31 Coleoptera families as a material processing result (Table 1). However, Staphylinidae remained undetermined, so its species number was not counted. The greatest species diversity had Cerambycidae (13 species), Nitidulidae (11 species) and Curculionidae (9 species). 
Table 1. Number of individuals (N), species (S), saproxylic species (Ssp), Shannon-Wiever (H'), Simpson's index (1-D), index of dominance of Berger and Parker (BP) from each Coleoptera family collected in five different biotopes

\begin{tabular}{|c|c|c|c|c|c|c|c|c|c|c|c|c|c|}
\hline \multirow{2}{*}{ Family } & \multicolumn{2}{|c|}{ Pine forest } & \multicolumn{2}{|c|}{ Lime forest } & \multicolumn{2}{|c|}{ Aspen forest } & \multicolumn{2}{|c|}{ Birch forest } & \multicolumn{2}{|c|}{ Oak forest } & \multicolumn{2}{|c|}{ Total } & \multirow[t]{2}{*}{ Ssp } \\
\hline & $\mathrm{N}$ & $\mathrm{S}$ & $\mathrm{N}$ & $\mathrm{S}$ & $\mathrm{N}$ & $\mathrm{S}$ & $\mathrm{N}$ & $\mathrm{S}$ & $\mathrm{N}$ & $\mathrm{S}$ & $\mathrm{N}$ & $\mathrm{S}$ & \\
\hline Carabidae & 0 & 0 & 1 & 1 & 2 & 2 & 0 & 0 & 0 & 0 & 3 & 2 & 1 \\
\hline Hydrochidae & 0 & 0 & 0 & 0 & 0 & 0 & 0 & 0 & 1 & 1 & 1 & 1 & 0 \\
\hline Histeridae & 5 & 3 & 2 & 1 & 3 & 2 & 0 & 0 & 0 & 0 & 10 & 3 & 2 \\
\hline Silphidae & 0 & 0 & 0 & 0 & 1 & 1 & 2 & 1 & 2 & 1 & 5 & 2 & 0 \\
\hline Staphylinidae* & 176 & 1 & 120 & 1 & 163 & 1 & 117 & 1 & 41 & 1 & 617 & 1 & 1 \\
\hline Lucanidae & 0 & 0 & 1 & 1 & 0 & 0 & 0 & 0 & 0 & 0 & 1 & 1 & 1 \\
\hline Scarabaeidae & 47 & 2 & 17 & 1 & 41 & 2 & 54 & 1 & 168 & 1 & 327 & 3 & 3 \\
\hline Scirtidae & 0 & 0 & 0 & 0 & 0 & 0 & 0 & 0 & 5 & 2 & 5 & 2 & 0 \\
\hline Buprestidae & 1 & 1 & 0 & 0 & 0 & 0 & 0 & 0 & 0 & 0 & 1 & 1 & 0 \\
\hline Throscidae & 1 & 1 & 0 & 0 & 0 & 0 & 0 & 0 & 0 & 0 & 1 & 1 & 1 \\
\hline Elateridae & 5 & 2 & 7 & 1 & 6 & 2 & 3 & 1 & 2 & 2 & 23 & 4 & 1 \\
\hline Cantharidae & 0 & 0 & 0 & 0 & 2 & 1 & 0 & 0 & 1 & 1 & 3 & 2 & 0 \\
\hline Dermestidae & 14 & 2 & 2 & 1 & 3 & 1 & 0 & 0 & 1 & 1 & 20 & 2 & 2 \\
\hline Ptinidae & 0 & 0 & 0 & 0 & 1 & 1 & 0 & 0 & 0 & 0 & 1 & 1 & 1 \\
\hline Cleridae & 4 & 2 & 0 & 0 & 1 & 1 & 0 & 0 & 0 & 0 & 5 & 3 & 3 \\
\hline Dasytidae & 1 & 1 & 0 & 0 & 2 & 2 & 1 & 1 & 0 & 0 & 4 & 2 & 2 \\
\hline Nitidulidae & 718 & 11 & 584 & 10 & 891 & 11 & 601 & 10 & 624 & 9 & 3418 & 11 & 10 \\
\hline Monotomidae & 1 & 1 & 4 & 1 & 3 & 1 & 1 & 1 & 2 & 1 & 11 & 1 & 1 \\
\hline Cucujidae & 2 & 1 & 0 & 0 & 2 & 1 & 0 & 0 & 0 & 0 & 4 & 1 & 1 \\
\hline Laemophloeidae & 1 & 1 & 0 & 0 & 0 & 0 & 0 & 0 & 0 & 0 & 1 & 1 & 1 \\
\hline Cerylonidae & 0 & 0 & 0 & 0 & 2 & 2 & 0 & 0 & 0 & 0 & 2 & 2 & 2 \\
\hline Coccinellidae & 2 & 1 & 0 & 0 & 3 & 2 & 1 & 1 & 0 & 0 & 6 & 4 & 0 \\
\hline Latridiidae & 1 & 1 & 1 & 1 & 1 & 1 & 0 & 0 & 0 & 0 & 3 & 2 & 2 \\
\hline Mycetophagidae & 2 & 1 & 6 & 1 & 4 & 4 & 2 & 1 & 2 & 1 & 16 & 2 & 2 \\
\hline Mordellidae & 1 & 1 & 0 & 0 & 0 & 0 & 1 & 1 & 0 & 0 & 2 & 1 & 1 \\
\hline Pyrochroidae & 0 & 0 & 0 & 0 & 1 & 1 & 0 & 0 & 0 & 0 & 1 & 1 & 1 \\
\hline Salpingidae & 0 & 0 & 0 & 0 & 0 & 0 & 0 & 0 & 1 & 1 & 1 & 1 & 1 \\
\hline Cerambycidae & 80 & 11 & 20 & 6 & 24 & 7 & 65 & 8 & 26 & 6 & 215 & 13 & 13 \\
\hline Chrysomelidae & 0 & 0 & 0 & 0 & 1 & 1 & 0 & 0 & 1 & 1 & 2 & 2 & 0 \\
\hline Brentidae & 0 & 0 & 1 & 1 & 0 & 0 & 0 & 0 & 0 & 0 & 1 & 1 & 0 \\
\hline Curculionidae & 67 & 5 & 35 & 3 & 95 & 3 & 30 & 4 & 40 & 2 & 267 & 9 & 4 \\
\hline Total & 1129 & 49 & 801 & 30 & 1252 & 50 & 787 & 31 & 917 & 31 & 4977 & 83 & 57 \\
\hline Total, \% & 22.7 & 59.0 & 16.1 & 36.1 & 25.2 & 60.2 & 15.8 & 37.3 & 20.2 & 37.3 & \multirow{3}{*}{\multicolumn{2}{|c|}{\begin{tabular}{l|l}
100 & 100 \\
\end{tabular}}} & 68.7 \\
\hline Total Ssp & \multicolumn{2}{|c|}{41} & \multicolumn{2}{|c|}{28} & \multicolumn{2}{|c|}{38} & \multicolumn{2}{|c|}{27} & \multicolumn{2}{|c|}{24} & & & 57 \\
\hline Total Ssp, \% & \multicolumn{2}{|c|}{71.9} & \multirow{2}{*}{\multicolumn{2}{|c|}{$\begin{array}{l}49.1 \\
2.19\end{array}$}} & \multirow{2}{*}{\multicolumn{2}{|c|}{$\begin{array}{l}66.7 \\
2.27\end{array}$}} & \multirow{2}{*}{\multicolumn{2}{|c|}{$\frac{47.4}{2.24}$}} & \multirow{2}{*}{\multicolumn{2}{|c|}{$\begin{array}{l}42.1 \\
1.82\end{array}$}} & & & 68.7 \\
\hline $\mathbf{H}^{\prime}$ & & & & & & & & & & & & & \\
\hline 1-D & \multicolumn{2}{|c|}{0.18} & \multicolumn{2}{|c|}{0.16} & \multicolumn{2}{|c|}{0.17} & & & & & & & \\
\hline BP & & & & & 0. & & & & & & & & \\
\hline
\end{tabular}

* - undet.

A large number of families were represented by one or two species (Carabidae, Hydrochidae, Silphidae, Lucanidae, Scirtidae, Buprestidae, Throscidae, Cantharidae, Dermestidae, Ptinidae, Dasytidae, Monotomidae, Cucujidae, Cerylonidae, Laemophloeidae, Latridiidae, Mycetophagidae, Mordellidae, Pyrochroidae, Salpingidae, Chrysomelidae and Brentidae).

A significant number of saproxyl taxa (57 species (68.7\%) of 23 families (74.2\%)) was collected in crown traps. The largest number of these species was caught in pine and aspen forests. However, the largest share of saproxyl species in relation to the total species number in the 
biotope was noted in lima (93.3\%) and birch forests $(87.1 \%)$. In these biotopes, it was the saproxyl species that formed the basis of the Coleoptera species diversity collected by fermental crown traps.

The general species diversity of biotopes was also different. It was highest in a pine forest. The Shannon-Wiever index reached its maximum in this biotope. The smallest ShannonWiever index was calculated for oak forest. Other biotopes had an average Shannon-Wiever index.

The greatest dominance (index of dominance of Berger and Parker) was found in the oak forest, the least one was in the lime forest. An increase in the Berger - Parker index, as well as in the Simpson index, means a decrease in diversity and an increase in the degree of one species domination. In the pine forest, one species Cychramus luteus (Fabricius, 1787) was dominating. However, the abundance of four to five species was quite high. In the lime and aspen forests, two species - Cryptarcha strigata (Fabricius, 1787) and Glischrochilus hortensis (Geoffroy, 1785) were dominating, and another five species were subdominant. In the birch forest, C. luteus and C. strigata were dominating, and the abundance of three to four more species was quite high. However, there are only three dominant species in the oak tree - C. strigata, Protaetia marmorata (Fabricus, 1792) and Soronia grisea (Linnaeus, 1758), they accounted for $77 \%$ of the total number of caught individuals for the entire season. This explains the high values of the Berger Parker index.

Cluster analysis by the Jaccard similarity index showed that the pine forest and aspen forest had the closest species composition of Coleoptera (Fig. 2). Perhaps this is due to the fact that Tilia cordata, with which many Coleoptera families are trophically connected, grows in the second tier of these habitats. The composition of the species in lime and birch forests was very similar and did not differ significantly from the oak forest species diversity.

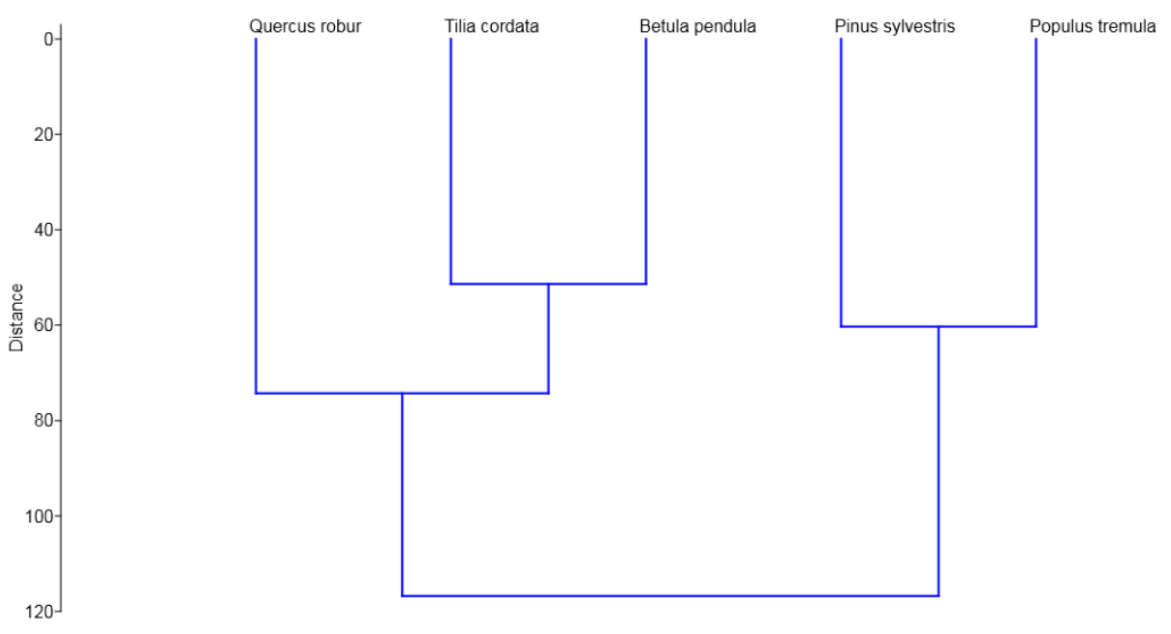


Figure 2. Jaccard's index of similarity based on the Coleoptera collected in five environments

Seasonal dynamics in terms of abundance and taxonomic diversity was characterized by one peak (Fig. 3). The Coleoptera abundance peak was recorded in mid-May in four biotopes (aspen, lime, pine and birch forests), while in oak forest it was recorded in early June. This increase is due to an increase in the abundance of two species, C. luteus and G. hortensis. An individuals' number increase occurred at the beginning of June in the oak forest due to a sharp C. strigata number increase.

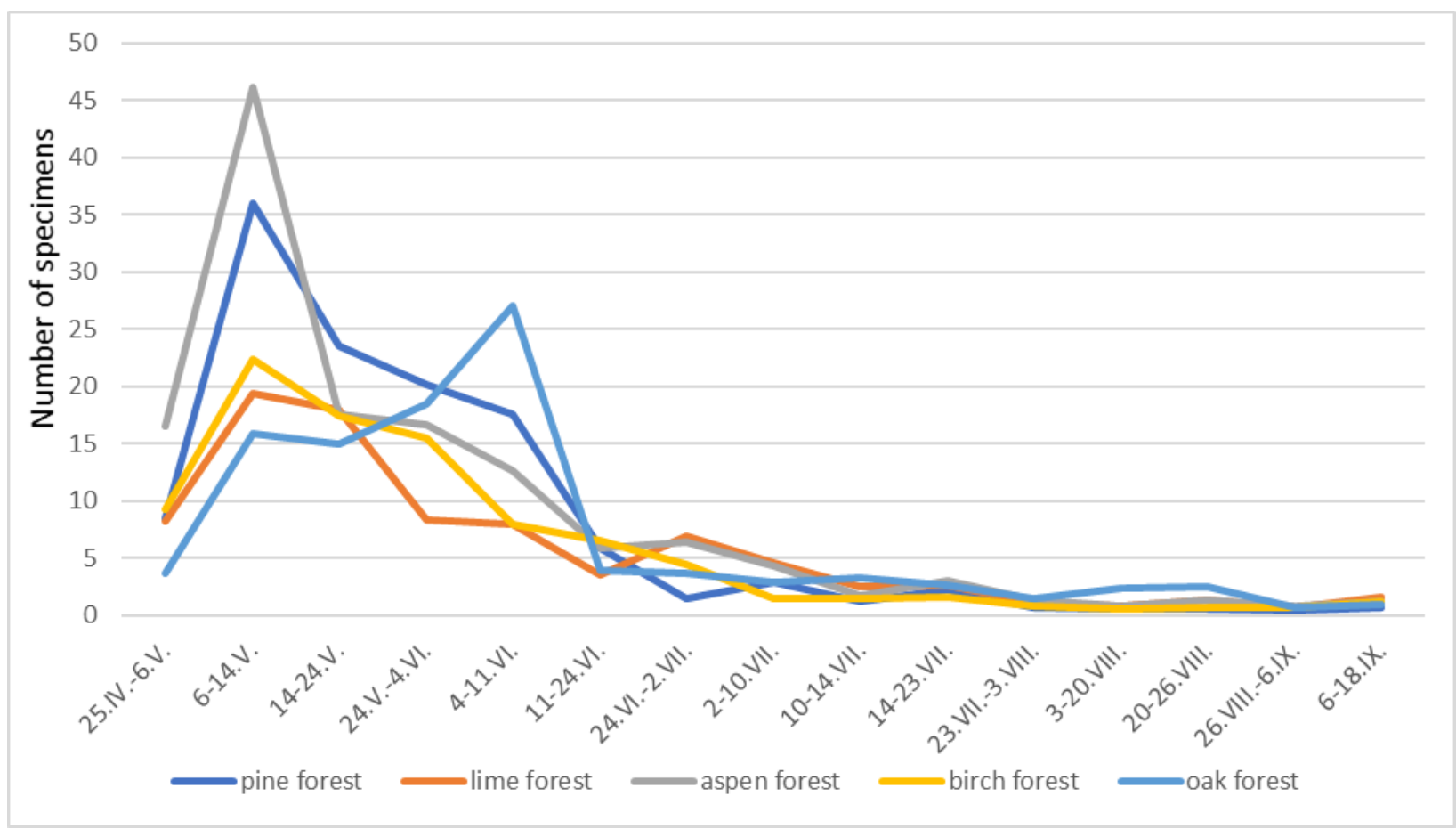

A

30

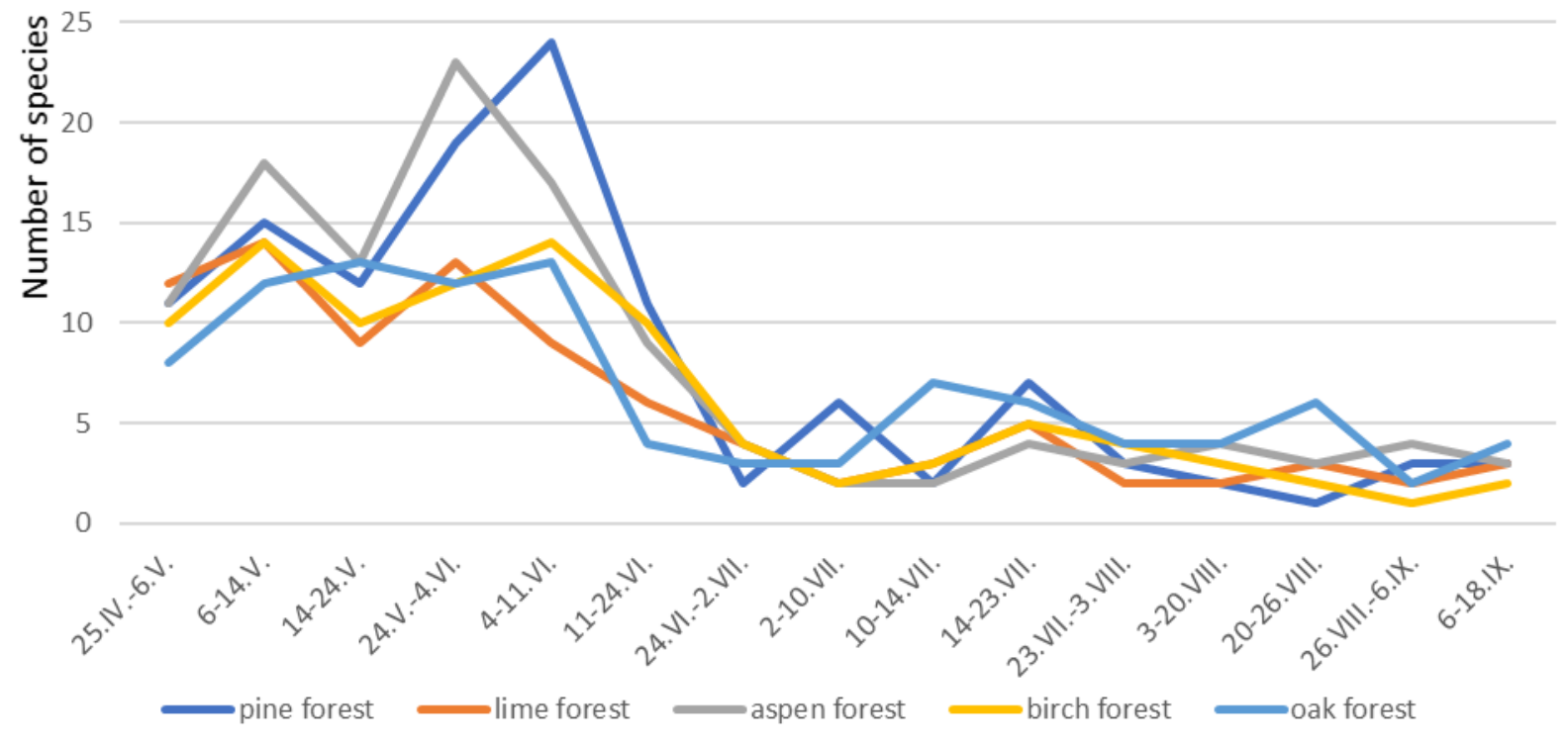




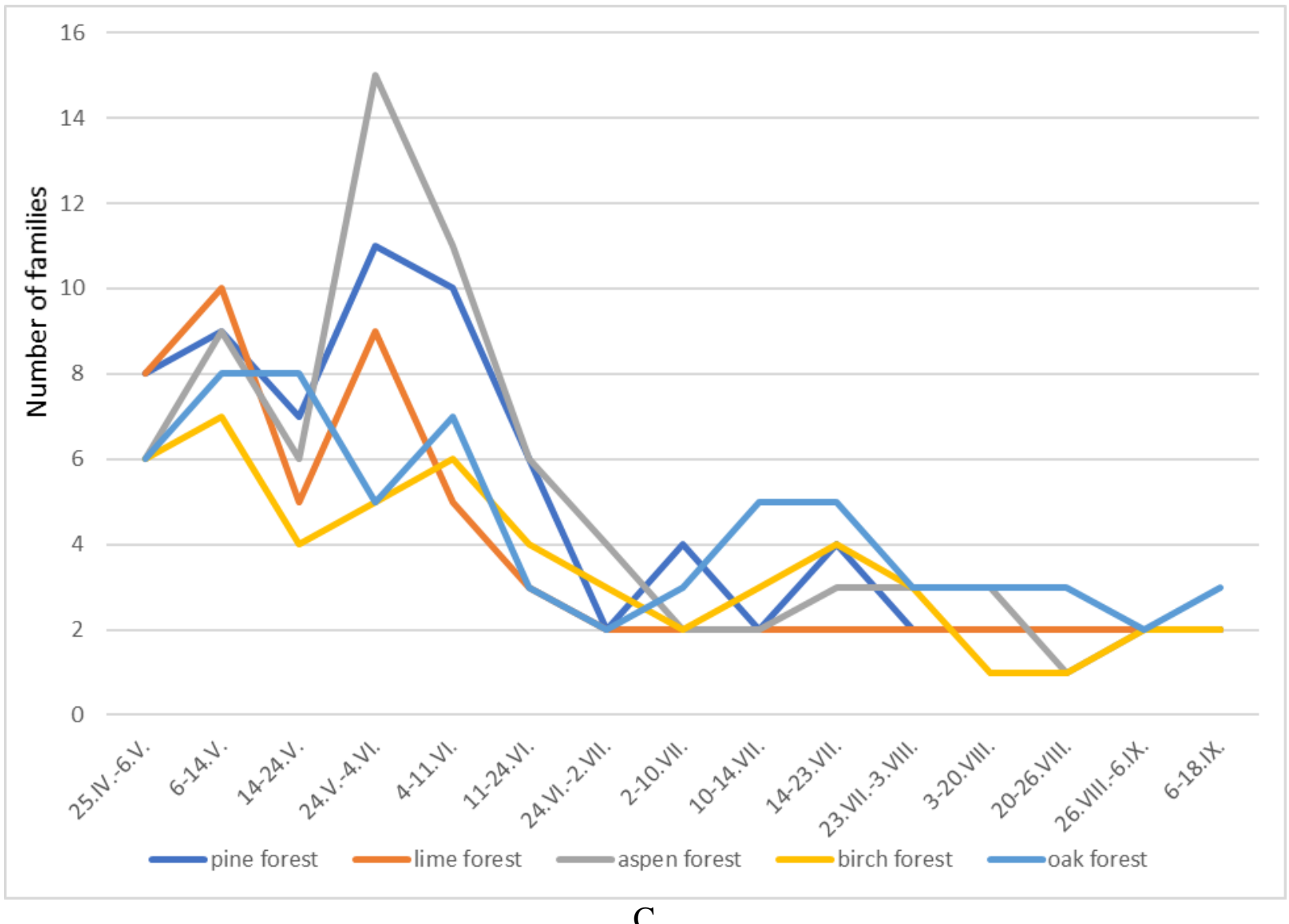

Figure 3. Seasonal dynamics in terms of abundance (A), species diversity (B), and families' diversity (C) of Coleoptera by biotopes

The individuals' number did not correlate with an increase in species diversity. The species number was small both in the beginning and in the middle of May. Families of Carabidae, Scirtidae, Throscidae, Elateridae, Dermestidae, Cucujidae, Latridiidae, Mycetophagidae, Curculionidae, which had not appeared in other seasons, were represented in May collections. For example, Dromius quadraticollis A. Morawitz, 1862, Dalopius marginatus (Linnaeus, 1758), Limonius minutus (Linnaeus, 1758), Contacyphon padi (Linnaeus, 1758), Contacyphon pubescens (Fabricius, 1792) Cortinicara gibbosa (Herbst, 1792) Litargus connexus (Geoffroy, 1785) were observed precisely in spring.

We observed the greatest species diversity and the maximum representation of the Coleoptera families in collections from late May to mid June. At that time, early spring species from the above families were active in some biotopes, and late spring and summer species began to appear. Then we observed a sharp decrease in indicators and only in the second half of July we saw species diversity increase to three - five species (one - three families) in different biotopes. Representatives of Staphylinidae, Nitidulidae and Silphidae were observed in traps in late August and September. 
Nitidulidae was the largest family trapped in crown traps. In total, 11 species of this family accounted for $68.7 \%$ of all Coleoptera collections. The increase in the individuals number was observed in the aspen forest (Table 1). Beetles of this family largely caused abundance dynamics in biotopes. From this family, we can distinguish some species whose activity dynamics we were able to describe.

Cryptarcha strigata (Fabricius, 1787) is a common species that was observed with a larger abundance in oak and aspen forests. Peak abundance was observed at the beginning of June; single adults occurred throughout the season in different biotopes (Fig. 4).

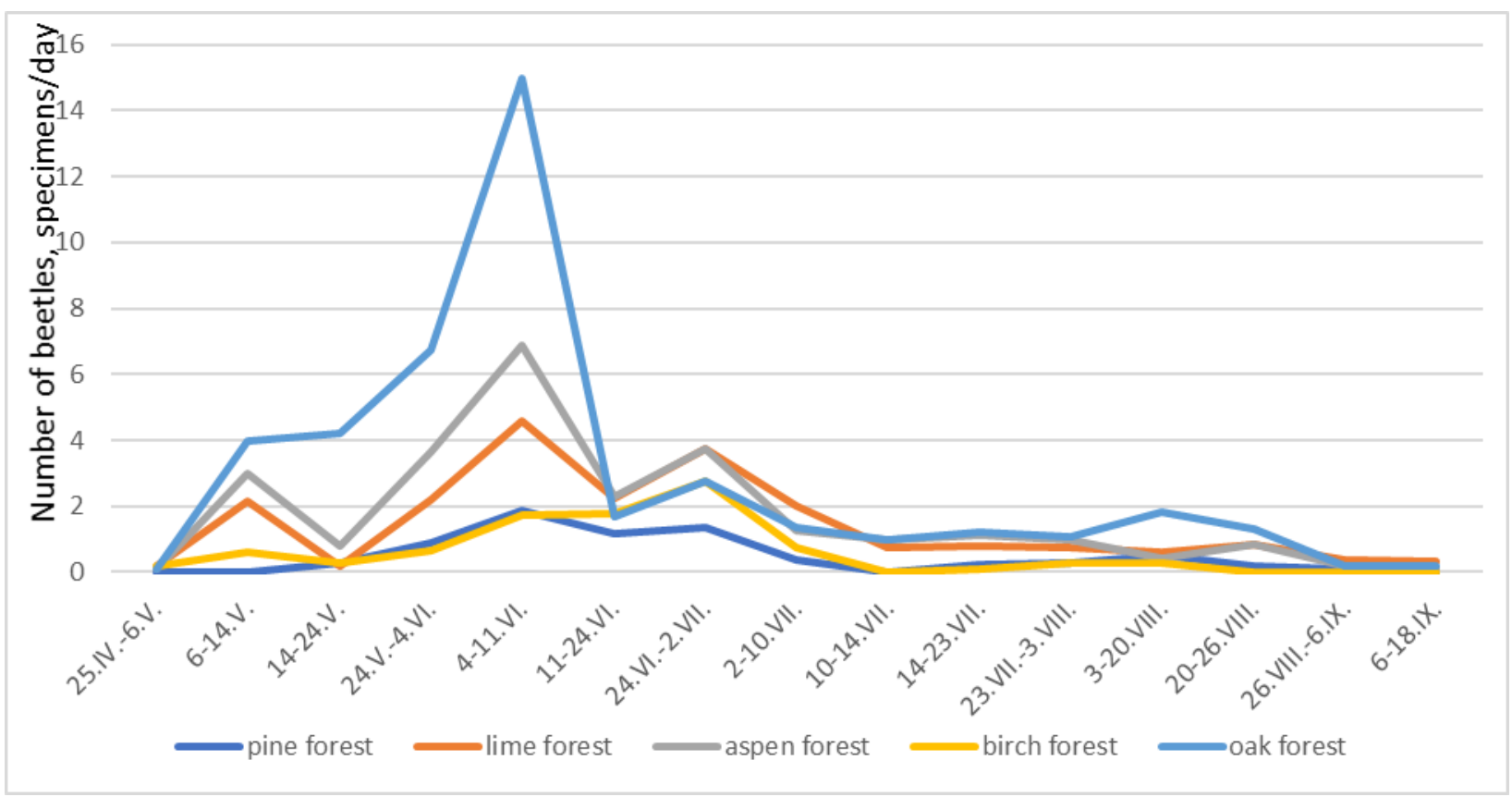

Figure 4. Seasonal abundance dynamics of Cryptarcha strigata in five biotopes. On the OY axis is the number of individuals, measured ind./day

The peak abundance of Glischrochilus hortensis (Geoffroy, 1785) was observed in midMay, then the beetles were not caught at all from late June to early June. Beetles began to be caught again only from the end of July (Fig. 5). Similar activity is noted in other regions (Nikitsky et al., 2016). 


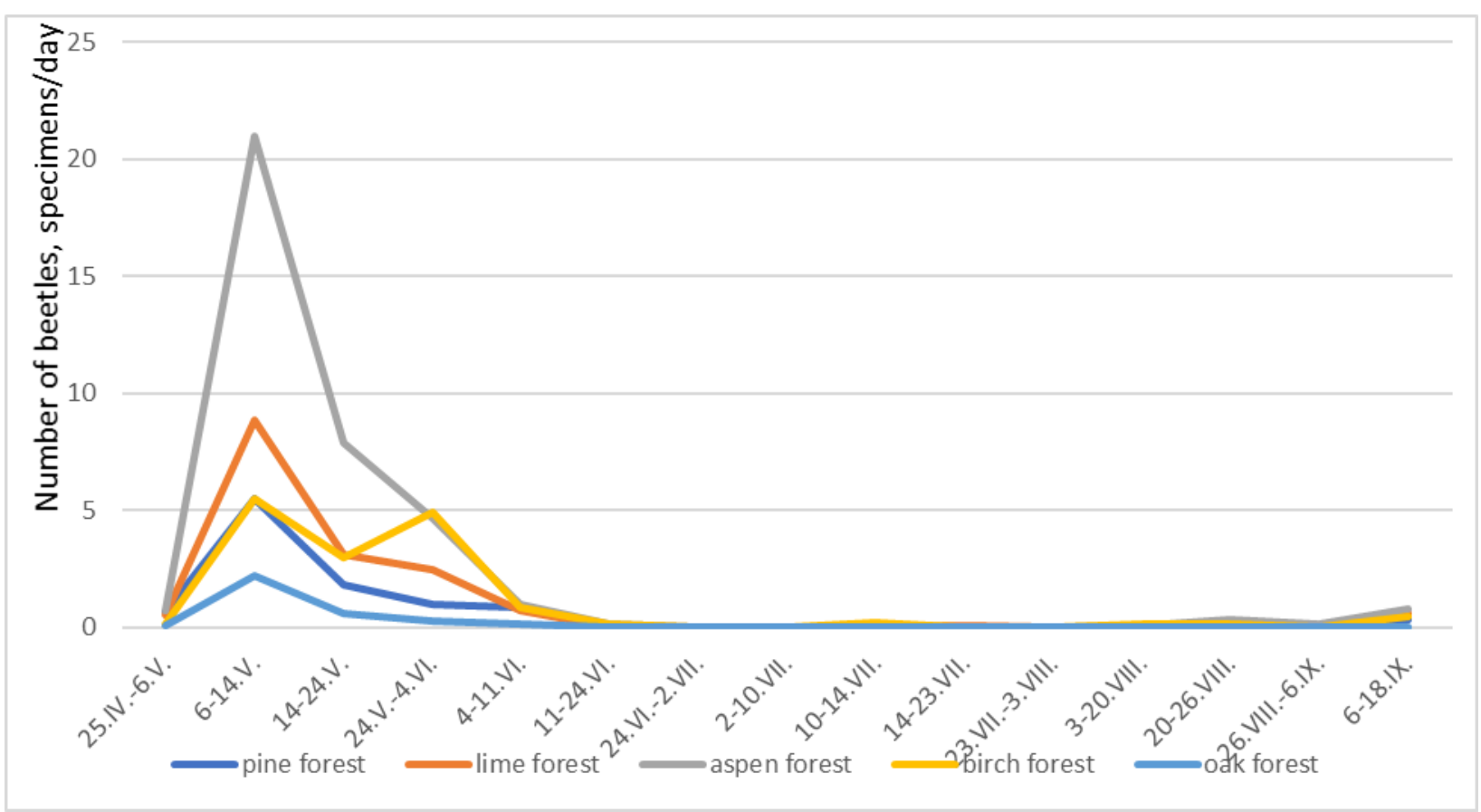

Figure 5. Seasonal abundance dynamics of Glischrochilus hortensis in five biotopes

The peak abundance of Glischrochilus grandis (Tournier, 1872) reached its highest values in mid-May (Fig. 6). Single specimens were found until the end of July, but the species was no longer caught from August. G. grandis reached the highest abundance in aspen and pine forests.

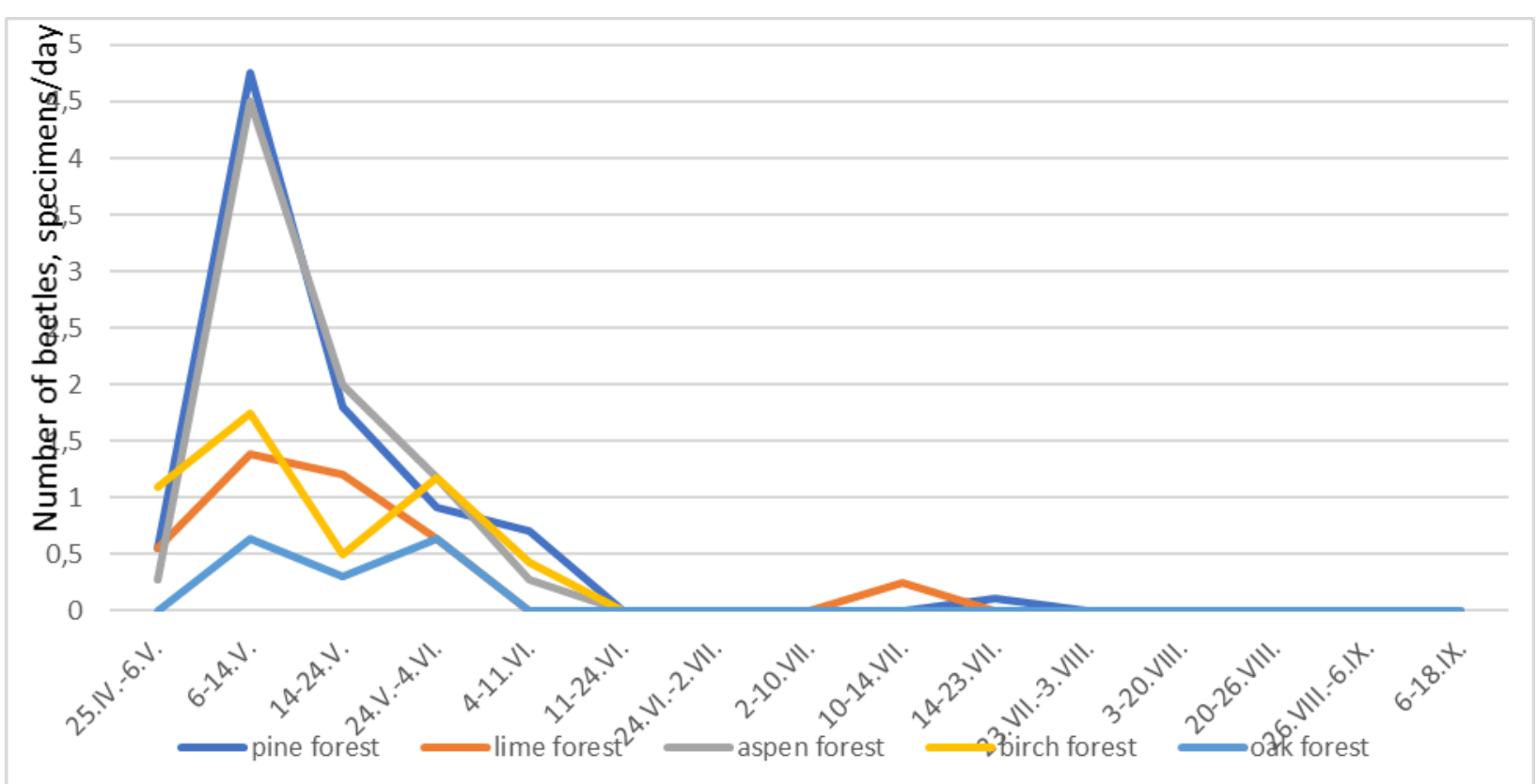

Figure 6. Seasonal abundance dynamics of Glischrochilus grandis in five biotopes

Cychramus luteus (Fabricius, 1787) had a temporarily extended cycle of maximum activity recorded in all biotopes in May (Fig. 7). The maximum abundance of adults was recorded in the pine, birch and aspen forests. In August, single individuals were found in some biotopes, and this species has not been observed in traps since the end of August. 


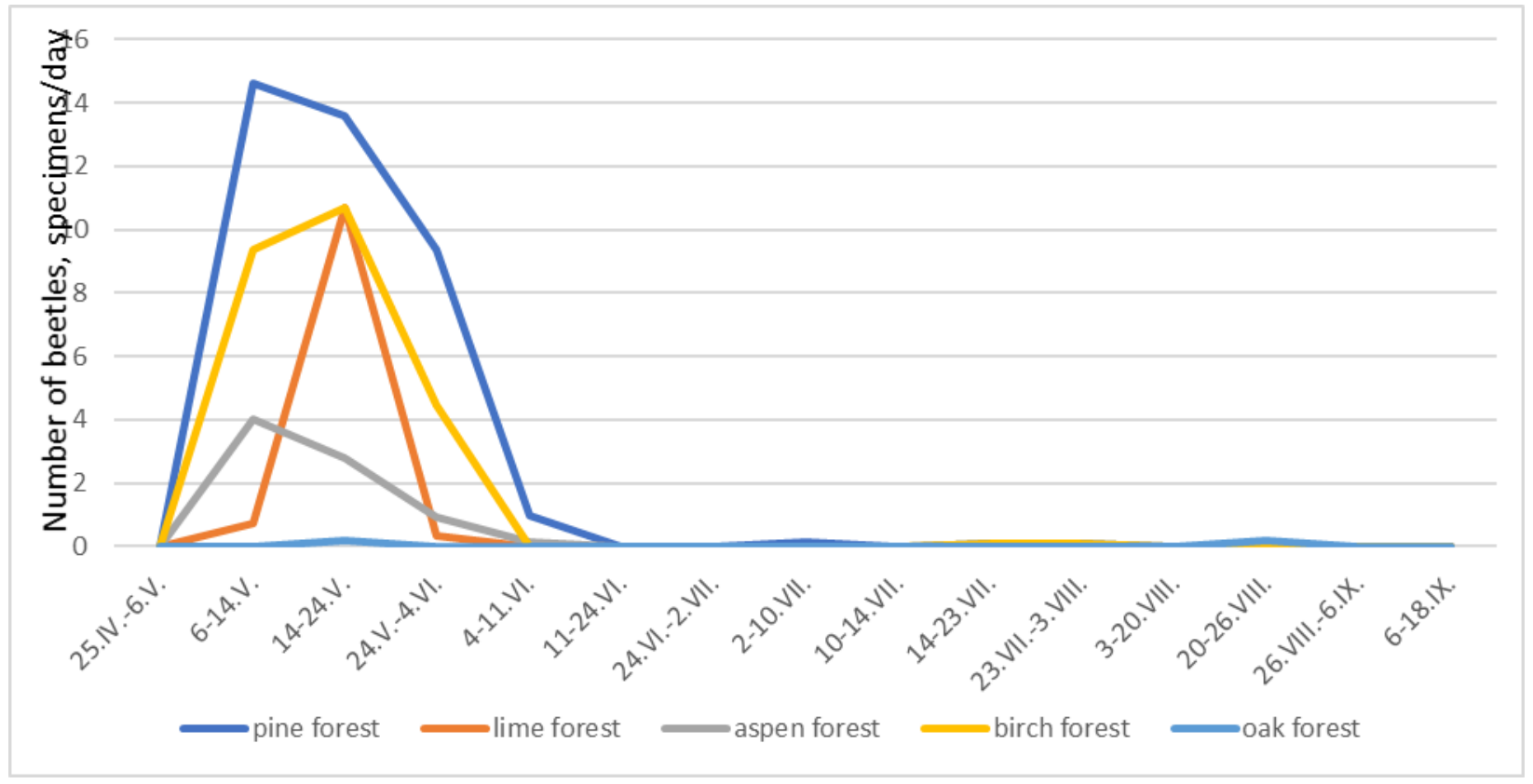

Figure 7. Seasonal abundance dynamics of Cychramus luteus in five biotopes

Soronia grisea (Linnaeus, 1758) had the largest abundance in the oak forest (Fig. 8). In the other four biotopes, its abundance was approximately similar. The main peak in abundance was observed in all biotopes from late May to early June. A small number of beetles were active in late August and September.

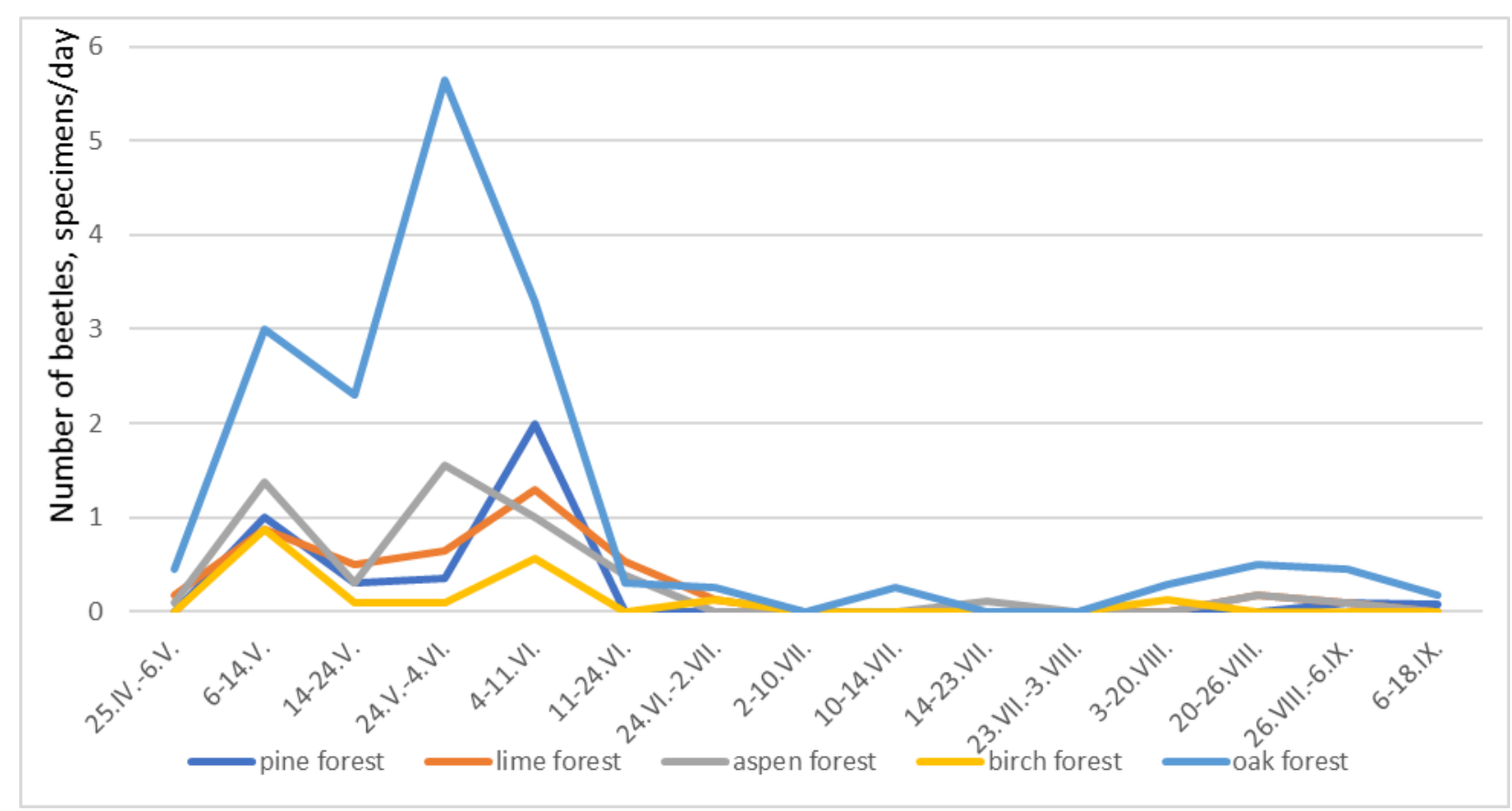

Figure 8. Seasonal abundance dynamics of Soronia grisea in five biotopes

Representative samples were also obtained for two more species Protaetia marmorata (Fabricus, 1792) (Scarabaeidae) and Anisandrus dispar (Fabricius, 1792) (Curculionidae: Scolytinae). The highest abundance of Protaetia marmorata was recorded in the oak forest (Fig. 9). In this biotope, the maximum abundance was recorded in the second half of May; later it decreased. In the 
other four biotopes, the peak was in June. At the end of July, Protaetia marmorata was not observed in any biotopes.

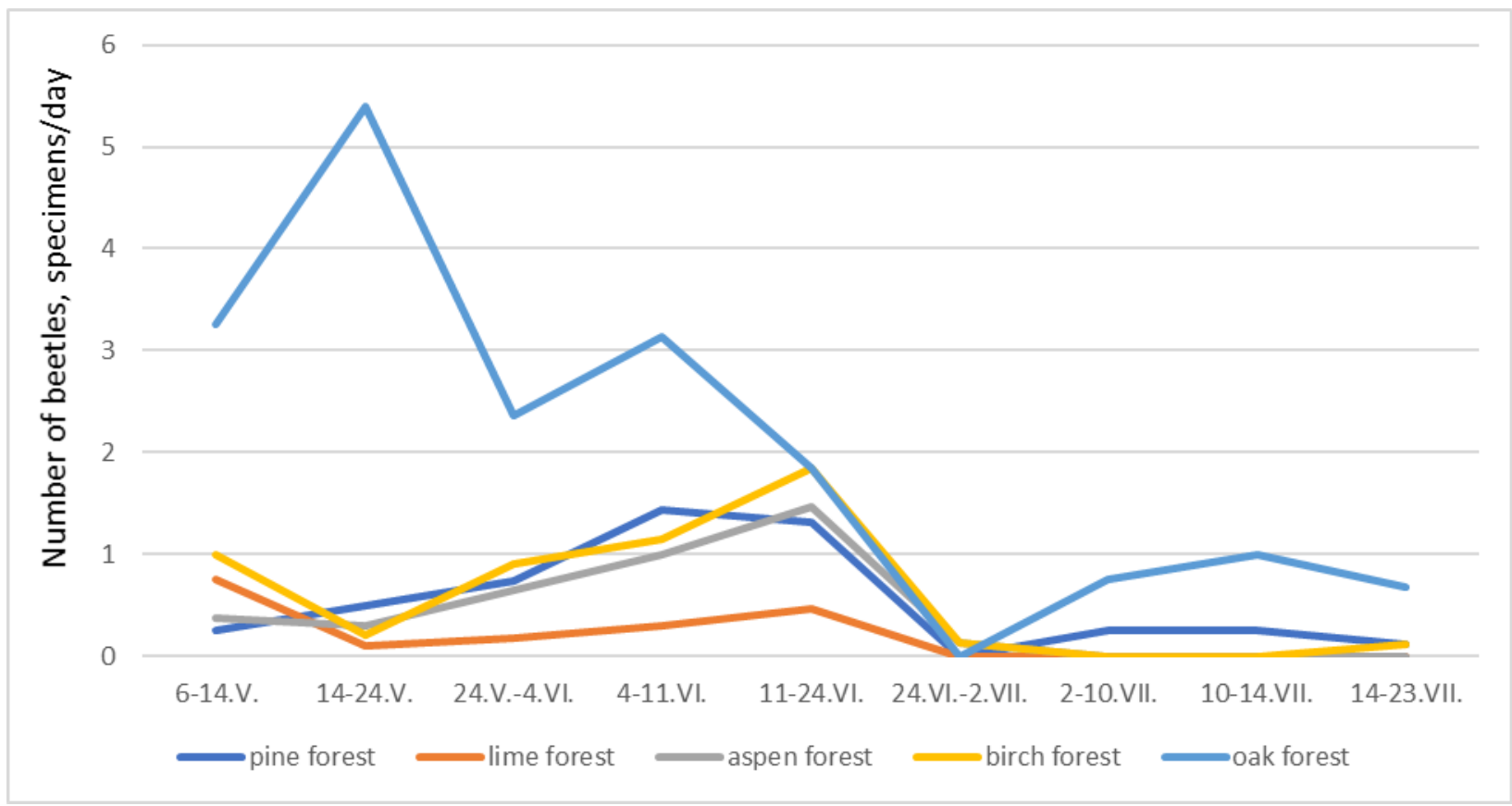

Figure 9. Seasonal abundance dynamics of Protaetia marmorata in five biotopes

The activity of Anisandrus dispar (Fabricius, 1792) was spring-and-early summer. This species appeared in significant numbers in traps from the very first days of exposure (Fig. 10). It predominated in the aspen and pine forest, and the smallest abundance was observed in the lime forest. After June 11, this species was no longer observed in traps.

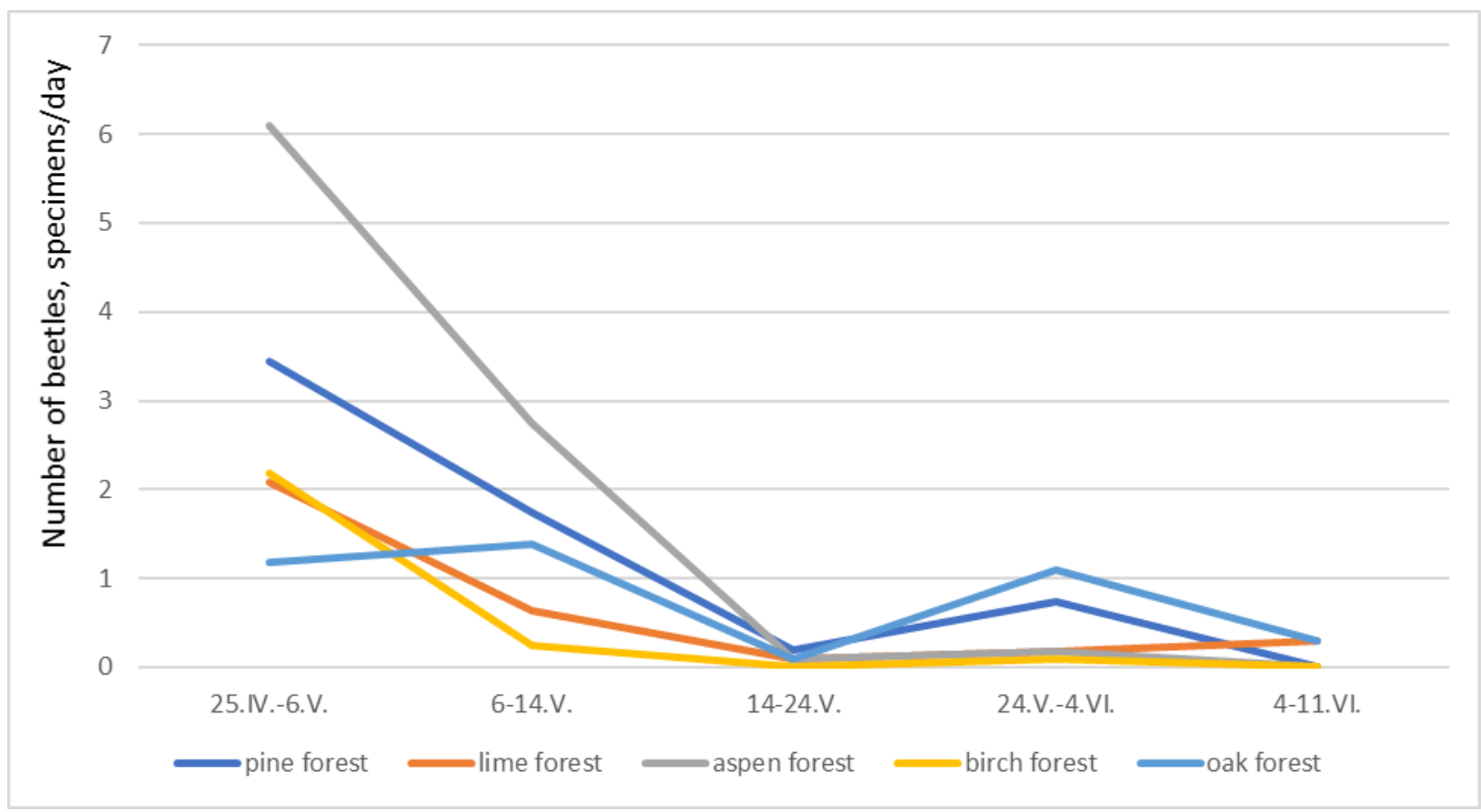

Figure 10. Seasonal abundance dynamics of Anisandrus dispar in five biotopes 


\section{Discussion}

Thus, different families and species appear in different seasons in a particular biotope. Many families are represented by one or two species in traps. This is especially true for families in which imagines are most active in spring and early summer. Some species of Dasytidae, Elateridae, Curculionidae, Scirtidae and other families are active precisely at these dates (Levesque \& Levesque, 1993, 2019; Speranza et al., 2009; Hardersen et al., 2014; Jakubowska et al., 2018). Saproxyl species constituted a significant part of the total species diversity, being the most abundant in pine and aspen forests. In present study, we demonstrated that these biotopes have the richer species diversity of beetles. This means that crown traps can be used to account for some of the Coleoptera ecological group species.

The species diversity dynamics is characterized in different biotopes by one activity peak observed in May. The peak number of beetles recorded in mid-May did not coincide with the species diversity and family diversity peak, the maximum of which was observed in late May and early June. Hardersen et al. (2014), Sawoniewicz (2015) obtained similar data on the number of beetles and activity dynamics.

Among biotopes, the highest species diversity was observed in the pine forest, and the smallest one was in the oak forest. At the same time, dominance was high in the oak forest, while it was the smallest in the lime forest. Typically, oak communities are considered biodiversity centers (Buse et al., 2008; Oleksa et al., 2013; Hardersen et al., 2014). However, our studies have not shown it. We assume that this is due to two reasons. Firstly, traps were located on branches deep in the trees' crowns, and some of the species that usually fly from nearby biotopes were not lured in this case. Great species diversity is directly related to exposure to solar radiation and increases with increasing sun exposure of substrate (Ranius \& Jansson, 2000; Lindhe \& Lindelöw, 2004). Secondly, the biotope vegetation was represented only by oak and elm, undergrowth and shrub layer were practically not presented. Under such conditions, species living in the bush layer were also not taken into account in catches.

On the other hand, other tree species, with which many species are trophically related, were fairly well represented. For example, foresters advise planting oaks in the undergrowth in order to increase the biodiversity of Coleoptera in pine forests (Buse et al., 2010). As the pine forest, the aspen forest has become the most diverse in vegetation. In the temperate zone forests, aspen is an important substrate for the habitat of a significant species number (Kolström \& Lumatjärvi, 2000; Martikainen, 2001; Sverdrup-Thygeson \& Ims, 2002). It is these two forest areas that showed a close species composition during cluster analysis.

In total, 11 Nitidulidae species accounted for more than 2/3 of the Coleoptera population. Cryptarcha strigata, Cychramus luteus and Glischrochilus hortensis had the highest numbers. 
Cryptarcha strigata imagines live near the sag of $Q$. robur fermenting sap, where the preimaginal phases develop; $P$. tremula is occasionally found in leaking juice (Kurochkin, 2007). The Cryptarcha strigata abundance was the highest in biotopes with a predominance of these species. The Cychramus luteus imagines are anthophiles and are found on flowers in the summer, then they switch to feeding on Armillaria mellea mushrooms, where the larvae develop. Imagineshibernate (Nikitsky et al., 1996). In our studies, single individuals were trapped during the summer; imagines were no longer observed from the end of August. The highest Glischrochilus hortensis abundance was observed in the aspen and lime forests. According to published data, imagines are found on the fer Q. robur fermenting sap and under the bark of fallen and dying trees B. pendula, P. tremula. Larvae develop under the bark of dying and damaged trees B. pendula, P. tremula, Q. robur and in their fermenting sap, and they can also be found on fermented berries, vegetables, and mushrooms (Burakowski et al., 1986; Oude, 1999; Kurochkin, 2007; Nikitsky et al., 2016).

Glischrochilus grandis is usually found on the decaying tree sap of birches and oaks, where larvae develop, on polypore, rotten berries, and it develops on different decaying substrates (Alekseev \& Nikitsky, 2008; Lasoń \& Holly, 2015; Nikitsky et al., 1996, 2016). This species was numerous surprisingly in a pine forest. We think that there was a well-defined hardwood undergrowth where this species could develop. The substrate for trapping (sugar and fermenting beer) also had a certain effect, attracting insects from other parts of the forest with prevailing not pine, but aspen and birch. According to published data, Soronia grisea lives in oak forests and mixed stands with the presence of oak, where it is often found in the sap of Q. robur, Salix (Nikitsky et al., 1996, 2016; Kurochkin, 2007).

The species Glischrochilus quadrisignatus (Say, 1835) is interesting. It is a North American spreading species (Keszthelyi, 2012). Price and Young (2006) found it associated with rotting fruit, corn, dung, carrion, wounded trees, a polypore fungus, and under the bark of black cherry. For Russia, its first find dates back to 1998 (Yaroslavl region) (Vlasov \& Nikitsky, 2015). It was found not only near human housing, in cities and rural areas, but also in natural ecosystems. Currently, it is known in many regions of Russia (Orlova-Bienkowskaja, 2019). The species abundance was low in the capture. In our opinion, in natural ecosystems, it still does not withstand competition with native species, the number of which is ten times higher.

Omosita discoidea (Fabricius, 1775) is common throughout its distribution range especially in southern Europe and more sporadic in the North. It is mainly associated with vertebrates in an advanced state of decomposition; larval development takes place on semi-dried and exposed bones (Mifsud \& Audisio, 2008). This species, apparently, was accidentally caught in crown traps. The species spread across Europe and North America (Majka \& Cline, 2006). 
Thus, we believe that crown traps with beer and sugar as bait are a good tool in the study of the Nitidulidae fauna. Avgin et al (2015) also caught several new species of Nitidulidae in Turkey on the beer bait. At the same time, many species from the Nitidulidae family are very well caught specifically for beer bait.

Representatives of other families are also caught with significant numbers for this type of bait. A fairly common species of Protaetia marmorata within the area inhabits mixed forests, deciduous, including floodplain forests, alleys, parks, forest belts and other similar biotopes (Tauzin, 2006; Shokhin, 2007; Oleksa et al., 2013; Urban \& Schulze, 2017). According to our unpublished data based on the capture by crown fermental traps, it can be concluded that Protaetia marmorata is found in a significantly larger number of biotopes than previously thought. Thus, the range of biotopes is wide. Oleksa et al. (2006) showed that there is no binding of this species to certain deciduous trees species, which made it possible to call it universal. In addition, individuals within individual trees have fairly close family ties (Oleksa et al., 2013). Larvae develop in the hollow of dead deciduous trees for three years (Tauzin, 2006; Urban \& Schulze, 2017). However, according to the results of our research, the Protaetia marmorata abundance was much higher in the oak forest, and in other four biotopes it was approximately at the same level. Therefore, we can say with certainty that Protaetia marmorata prefers to breed in the places where are oaks growing close to other tree species.The species number increase from June 11 to 24 in other biotopes, except for the oak tree, can be explained by the migration (resettlement) of individuals.

Anisandrus dispar is a polyphage on deciduous trees and it prefers Acer, Alnus, Populus, Quercus, Crataegus, Sorbus, Corylus, Castanea, Malus (Kovach \& Gorsuch, 1985; Speranza et al., 2009; Saruhan \& Akyol, 2012; Shtapova \& Petrov, 2018). Imago activity depends on humidity and temperature. As in our studies, other scientists revealed the maximum activity of this species from the end of April to the first half of May. However, Anisandrus dispar ceased to be caught in crown traps from mid-June, while according to the literature (Speranza et al., 2009; Saruhan \& Akyol, 2012; Sarikaya \& Sayin, 2015), the second peak of its activity is observed in August. We assume that this species needs to be fed with sugars to get carbohydrates only for the first time after wintering the imagines. Further, this is not necessary, so it ceases to be caught in fermented mixtures.

\section{References}

Alekseev V.I. \& Nikitsky N.B., 2008, Rare and new for the fauna of the Baltic States Beetles (Coleoptera) from the Kaliningrad Region. Acta Zoologica Lituanica 18(4): 254-259. Alonso-Zarazaga M.A., Barrios H., Borovec R., Bouchard P., Caldara R., Colonnelli E., Gültekin L., Hlaváč P., Korotyaev B., Lyal C.H.C., Machado A., Meregalli M., Pierotti H., 
Ren L., Sánchez-Ruiz M., Sforzi A., Silfverberg H., Skuhrovec J., Trýzna M., Velázquez de Castro A.J. \& Yunakov N.N., 2017, Cooperative Catalogue of Palaearctic Coleoptera Curculionoidea. Monografías electrónicas S.E.A. Vol. 8. Sociedad Entomológica Aragonesa S.E.A. Zaragoza (Spain), 729 pp.

Avgin S.S., Antonini G., Lasoń A., Jansson N., Abacigil T.Ö., Varli S.V., De Biase A. \& Audisio P., 2015, New data on distribution, ecology, and taxonomy of Turkish Nitidulidae (Coleoptera). Turkish Journal Zoology 39: 314-322. doi:10.3906/zoo-140227

Bouget C., Brustel H., Brin A. \& Noblecourt T., 2008, Sampling saproxylic beetles with window flight traps: methodological insights. Revue d'Ecologie, Terre et Vie, Société nationale de protection de la nature. Suppt. 10: 21-32.

Burakowski B., Mroczkowski M. \& Stefańska J., 1986, Chrząszcze Coleoptera - Cucujoidea, cz. 1. Katalog Fauny Polski 23(12): 1-266.

Buse J., Levanony T., Timm A., Dayan T. \& Assmann T., 2008, Saproxylic beetle assemblages of three managed oak woodlands in the Eastern Mediterranean. Zool. Middle East 45: 55-66.

Buse J., Levanony T., Timm A., Dayan T. \& Assmann T., 2010, Saproxylic beetle assemblages in the Mediterranean region: Impact of forest management on richness and structure. Forest Ecology and Management 259: 1376-1384. doi: 10.1016/j.foreco.2010.01.004

Byk A. \& Węgrzynowicz P., 2015, The structure and seasonal dynamics of coprophagous Scarabaeoidea (Coleoptera) communities in later developmental stages of pine stands in NW Poland. J. Entomol. Res. Soc. 17(3): 39-57.

Catalogue of Palaearctic Coleoptera, 2007, Vol. 4: Elateroidea-Derodontoidea-Bostrichoidea. Lymexyloidea-Cleroidea-Cucujoidea, I. Löbl, A. Smetana (eds). Apollo Books, Stenstrup, $935 \mathrm{pp}$.

Catalogue of Palaearctic Coleoptera, 2008, Vol. 5: Tenebrionoidea, I. Löbl, A. Smetana (eds). Apollo Books, Stenstrup, 670 pp.

Catalogue of Palaearctic Coleoptera, 2010, Vol. 6: Chrysomeloidea, I. Löbl, A. Smetana (eds). Apollo Books, Stenstrup, 924 pp.

Catalogue of Palaearctic Coleoptera, 2011, Vol. 7: Curculionoidea I / Löbl I., Smetana A. (eds.). Apollo Books, Stenstrup, 373 pp.

Catalogue of Palaearctic Coleoptera, 2013, Vol. 8: Curculionoidea II / Löbl I., Smetana A. (eds.). Apollo Books, Stenstrup, 707 pp.

Catalogue of Palaearctic Coleoptera, 2015, Vol. 2/1: Revised and updated version. Hydrophiloidea - Staphylinoidea, I. Löbl, D. Löbl (eds). Brill, Leiden-Boston, 1702 pp.

Catalogue of Palaearctic Coleoptera, 2016, Vol. 3: Revised and updated version. Scarabaeoidea - Scirtoidea - Dascilloidea - Buprestoidea - Byrrhoidea, 2016, I. Löbl, D. Löbl (eds). Brill, Leiden-Boston, 983 pp.

Catalogue of Palaearctic Coleoptera, 2017, Vol. 1: Revised and updated version. Archostemata Adephaga - Myxophaga, I. Löbl, D. Löbl (eds). Brill, Leiden-Boston, 1443 pp.

Egorov L.V. \& Ivanov A.V., 2018, Beetles (Insecta, Coleoptera), collected by fermenting bait crown traps in Chuvashia. Proceedings of the Mordovia State Nature Reserve 21: 191204 (in Russian).

Faccoli M., Favaro R., Smith M.T. \& Wu J., 2015, Life history of the Asian longhorn beetle Anoplophora glabripennis (Coleoptera Cerambycidae) in southern Europe. Agricultural and Forest Entomology 17(2): 188-196. https://doi.org/10.1111/afe.12096

Hammer Ø., Harper D.A.T. \& Ryan P.D., 2001, PAST: Paleontological statistics soft-ware package for education and data analysis. Palaeontologia Electronica 4(1): 9.

Handley K., Hough-Goldstein J., Hanks L.M., Millar J.G. \& D’Amico V., 2015, Species richness and phenology of cerambycid beetles in urban forest fragments of Northern Delaware. Ann. Entomol. Soc. Am. 108(3): 251-262. doi: 10.1093/aesa/sav005 
Hardersen S., Curletti G., Leseigneur L., Platia G., Liberti G., Leo P., Cornacchia P. \& Gatti E., 2014, Spatio-temporal analysis of beetles from the canopy and ground layer in an Italian lowland forest. Bulletin of Insectology 67(1): 87-97.

Jakubowska M., Bocianowski J. \& Nowosad K., 2018, Seasonal fluctuation of Agriotes lineatus, A. obscurus and A. sputator click beetles caught using pheromone traps in Poland. Plant Protect. Sci. 54(2): 118-127. doi: 10.17221/39/2016-PPS

Kašák J., Foit J. \& Hučín M., 2017, Succession of ground beetle (Coleoptera: Carabidae) communities after windthrow disturbance in a montane Norway spruce forest in the Hrubý Jeseník Mts. (Czech Republic). Cent. Eur. For. J. 63: 180-187. doi: 10.1515/forj-20170016

Keszthelyi S., 2012, Evaluation of flight phenology and number of generations of the fourspotted sap beetle, Glischrochilus quadrisignatus in Europe. Bulletin of Insectology 65(1): 9-16.

Khapugin A.A. \& Ruchin A.B. 2019. Red Data Book of vascular plants of the Mordovia State Nature Reserve, a protected area in European Russia. Wulfenia 26: 53-71.

Khapugin A.A., Vargot E.V. \& Chugunov G.G., 2016, Vegetation recovery in fire-damaged forests: a case study at the southern boundary of the taiga zone. Forestry Studies 64: 3950.

Kolström M. \& Lumatjärvi J., 2000, Saproxylic beetles on aspen in commercial forests: a simulation approach to species richness. Forest Ecology and Management 126(2): 113-120. https://doi.org/10.1016/S0378-1127(99)00095-X

Kovach J. \& Gorsuch C.S., 1985, Survey of ambrosia beetle species infesting South Carolina peach orchards and a taxonomic key for the most common species. Journal of Agricultural Entomology 2: 238-247.

Kurochkin A.S., 2007, Fauna and bionomy of sap beetles (Coleoptera, Nitidulidae) and kateretid beetles (Coleoptera, Kateretidae) of Krasnosamarskoe forestry farm (Samara Region, Russia). Vestnik of Samara University. Natural Science Series 8(58): 120-128 (in Russian).

Lachat T., Wermelinger B., Gossner M.M., Bussler H., Isacsson G. \& Müller J., 2012, Saproxylic beetles as indicator species for dead-wood amount and temperature in European beech forests. Ecological Indicators 23: 323-331. http://dx.doi.org/10.1016/j.ecolind.2012.04.013

Lasoń A. \& Holly M., 2015, Glischrochilus grandis Tournier, 1872 - new species of beetle for the Polish fauna and new data on the occurrence of genus Glischrochilus Reitter, 1873 (Coleoptera: Nitidulidae: Cryptarchinae). Acta Entomologica Silesiana 23: 1-4.

Levesque C. \& Levesque G.Y., 1993, Abundance and seasonal activity of Elateroidea (Coleoptera) in a raspberry plantation and adjacent sites in southern Québec, Canada. Coleopterists Bulletin 47: 269-277.

Levesque C. \& Levesque G.Y., 1996, Seasonal dynamics of rove beetles (Coleoptera: Staphylinidae) in a raspberry plantation and adjacent sites in eastern Canada. Journal of the Kansas Entomological Society 69(4): 285-301.

Levesque C. \& Levesque G.Y., 2019, A five-year study of the flying beetles (Coleoptera) from a grassland and an adjacent woods in Southern Québec (Canada). Great Lakes Entomologist 52 (1-2): 45-52.

Lindhe A. \& Lindelöw Å., 2004, Cut high stumps of spruce, birch, aspen and oak as breeding substrates for saproxylic beetles. Forest Ecology and Management 203: 1-20.

Majka C.G. \& Cline A.R., 2006, The Nitidulidae and Kateretidae (Coleoptera) of Nova Scotia and Prince Edward Island. Canadian Entomologist 138: 314-332.

Martikainen P., 2001, Conservation of threatened saproxylic beetles: significance of retained aspen Populus tremula on clearcut areas. Ecological Bulletins 49: 205-218. 
McCauley S.J., Hammond J.I., Frances D.N. \& Mabry K.E., 2015, Effects of experimental warming on survival, phenology and morphology of an aquatic insect (Odonata). Ecol Entomol. 40(3): 211-220. doi: 10.1111/een.12175

Memmott J., Craze P.G., Waser N.M. \& Price M.V., 2007, Global warming and the disruption of plant-pollinator interactions. Ecology Letters 10(8): 710-717. https://doi.org/10.1111/j.1461-0248.2007.01061.x

Mifsud D. \& Audisio P., 2008, The Kateretidae and Nitidulidae of the Maltese Archipelago (Coleoptera). Bulletin Entomological Society Malta 1: 15-37.

Miller-Rushing A.J., Hoye T.T., Inouye D.W. \& Post E., 2010, The effects of phenological mismatches on demography. Philos. Trans. R. Soc. Lond. 365(1555): 3177-3186. doi: 10.1098/rstb.2010.0148

Nasir S., Akram W. \& Ahmed F., 2012, The population dynamics, ecological and seasonal activity of Paederus fuscipes Curtis (Staphylinidae; Coleoptera) in the Punjab, Pakistan. APCBEE Procedia 4: 36-41. https://doi.org/10.1016/j.apcbee.2012.11.007

Negrobov S.O., 2009, Seasonal dynamics of scarab beetles (Coleoptera, Lamellicornia) in Voronezh Province. Entomological Review. 89(1): 113-115. https://doi.org/10.1134/S0013873809010163

Nikitsky N.B., Mamontov S.N. \& Vlasenko A.S., 2016, New data of beetles from Tula abatis forests (Coleoptera: Nitidulidae-Scolytidae) collected in window traps. Bulletin of Moscow Society of Naturalists, Biological series 121(6): 25-37 (in Russian).

Nikitsky N.B., Osipov I.N., Chemeris M.V., Semenov V.B. \& Gusakov A.A., 1996, The beetles of the Prioksko-Terrasny Biosphere Reserve - xylobiontes, mycetobiontes and Scarabaeidae. Archives of zoological museum Moscow State University XXXVI: 1-197 (in Russian).

Oleksa A, Chybicki I.J., Gawronski R., Svensson G.P. \& Burczyk J., 2013, Isolation by distance in saproxylic beetles may increase with niche specialization. Journal Insects Conservation 17: 219-233. doi: 10.1007/s10841-012-9499-7

Oleksa A., Ulrich W. \& Gawronski R. 2006. Occurrence of the marbled rose-chafer (Protaetia lugubris Herbst, Coleoptera, Cetoniidae) in rural avenues in northern Poland. Journal Insects Conservation 10: 241-247. https://doi.org/10.1007/s10841-005-4830-1

Orlova-Bienkowskaja M.J. (ed.), 2019, Inventory on alien beetles of European Russia. Mukhametov G.V., Livny, 882 pp. (in Russian).

Oude J.E., 1999, Naamlijst van de glanskevers van Nederland en het omliggende gebied (Coleoptera: Nitidulidae and Brachypteridae). Nederlandse Faunistische Mededelinge 8: 1132.

Pau S., Wolkovich E.M., Cook B.I., Davies T.J., Kraft N.J.B., Bolmgren K., Betancourt J.L. \& Cleland E.E., 2011, Predicting phenology by integrating ecology, evolution and climate science. Glob. Change Biol. 17: 3633-3643. doi:10.1111/j.1365-2486.2011.02515.x

Parmesan C., 2006, Ecological and evolutionary responses to recent climate change. Annu. Rev. Ecol. Evol. Syst. 37: 637-669.

Peet R.K., 1974, The measurement of species diversity. Annual Review of Ecology and Systematics 5: 285-307. doi:10.1146/annurev.es.05.110174.001441

Pospelova E.B., Pospelov I.N. \& Orlov M.V., 2017, Climate change in Eastern Taimyr over the last 80 years and the warming impact on biodiversity and ecosystem processes in its territory. Nature Conservation Research 2(3): 48-60. http://dx.doi.org/10.24189/ncr.2017.040

Post E. \& Forchhammer M.C., 2008, Climate change reduces reproductive success of an Arctic herbivore through trophic mismatch. Phil. Trans. R. Soc. B363: 2369-2375. doi:10.1098/rstb.2007.2207

Pozsgai G. \& Littlewood N.A., 2014, Ground beetle (Coleoptera: Carabidae) population declines and phenological changes: Is there a connection? Ecological Indicators 41: 15-24. http://dx.doi.org/10.1016/j.ecolind.2014.01.029 
Price D.L., 2004, Species diversity and seasonal abundance of scarabaeoid dung beetles (Coleoptera: Scarabaeidae, Geotrupidae and Trogidae) attracted to cow dung in Central New Jersey. Journal of the New York Entomological Society 112(4): 334-347.

Price M.B. \& Young D.K., 2006, An annotated checklist of Wisconsin sap and short-winged flower beetles (Coleoptera: Nitidulidae, Kataretidae). Insecta Mundi 20(1-2): 68-84.

Ranius T. \& Jansson N., 2000, The influence of forest regrowth, original canopy cover and tree size on saproxylic beetles associated with old oaks. Biological Conservation 95: 85-94.

Redolfi De Zan L., Bellotti F., D’Amato D. \& Carpaneto G.M., 2014, Saproxylic beetles in three relict beech forests of central Italy: analysis of environmental parameters and implications for forest management. Forest Ecology and Management 328: 229-244. http://dx.doi.org/10.1016/j.foreco.2014.05.040

Ruchin A.B., Alekseev S.K. \& Khapugin A.A., 2019a, Post-fire fauna of carabid beetles (Coleoptera, Carabidae) in forests of the Mordovia State Nature Reserve (Russia). Nature Conservation Research 4(Suppl.1): 11-20. https://dx.doi.org/10.24189/ncr.2019.009

Ruchin A.B., Alekseev S.K. \& Semishin G.B., 2019b, Seasonal activity dynamics of imago Carabus coriaceus Linnaeus, 1758 (Coleoptera, Carabidae) in mixed forests. Proceedings of the Mordovia State Nature Reserve 23: 239-244.

Ruchin A.B. \& Egorov L.V., 2017, Overview of insect species included in the Red Data Book of Russian Federation in the Mordovia State Nature Reserve. Nature Conservation Research 2(Suppl. 1): 2-9 (in Russian). doi: 10.24189/ncr.2017.016

Ruchin A.B. \& Egorov L.V., 2018, Beetles (Insecta, Coleoptera), collected using fermental crown trap in the Republic of Mordovia. Report 1. Mordovia State Nature Reserve. Scientific Proceedings of the State Nature Reserve "Prisursky”. 33: 209-215 (in Russian).

Ruchin A.B., Egorov L.V. \& Semishin G.B. 2018. Fauna of click beetles (Coleoptera: Elateridae) in the interfluve of Rivers Moksha and Sura, Republic of Mordovia, Russia. Biodiversitas 19(4): 1352-1365. doi: 10.13057/biodiv/d190423

Ruchin A.B., Egorov L.V., Khapugin A.A., Vikhrev N.E. \& Esin M.N., 2020, The use of simple crown traps for the insects collection. Nature Conservation Research 5(1): 87-107. https://dx.doi.org/10.24189/ncr.2020.008

Ruchin A.B. \& Mikhailenko A.P., 2018, Fauna of mantids and orthopterans (Insecta: Mantodea, Orthoptera) of the Mordovia State Nature Reserve, Russia. Biodiversitas 19(4): 11941206. doi: 10.13057/biodiv/d190403

Samach A. \& Coupland G., 2000, Time measurement and the control of flowering in plants. Bioessays 22: 38-47.

Sarikaya O. \& Sayin H., 2015, Observations on the Flight Activities of Two Ambrosia Beetles Anisandrus dispar (Fabricius, 1792) and Xyleborinus saxesenii (Ratzeburg, 1837) in Kasnak Oak Forest Nature Protection Area in the South Western of Turkey. International Journal of Agriculture Innovations and Research 4(2): 357-360.

Saruhan I. \& Akyol H., 2012, Monitoring population density of Anisandrus dispar and Xyleborinus saxesenii (Coleoptera: Scolytinae, Curculionidae) in hazelnut orchards. African J. Biotechnol. 11: 4202-4207.

Sawoniewicz M., 2015, Seasonal dynamics of saproxylic beetles (Coleoptera) occurring in decaying birch (Betula spp.) wood in the Kampinos National Park. Forest Research Papers 76(3): 213-220. doi: 10.1515/frp-2015-0020

Speranza S., Bucicni D. \& Paparatti B., 2009, New observation on biology of European shothole borer (Xyleborus dispar (F.) on hazel in North Latium (Central Italy). Acta Hortic. 845: 539-542.

Shokhin I.V., 2007, Contribution to the fauna of lamellicorn beetles (Coleoptera, Scarabaeoidea) of Southe rn Russia, with some nomenclatural changes in the family Scarabaeidae. Caucasian Entomological Bull. 3(2): 105-185 (in Russian). 
Singer M.C. \& Parmesan C., 2010, Phenological asynchrony between herbivorous insects and their hosts: signal of climate change or pre-existing adaptive strategy? Philos. Trans. B. 365(1555): 3161-3176. doi: 10.1098 / rstb.2010.0144

Shtapova N.N. \& Petrov A.V., 2018, Fauna of bark beetles (Coleoptera: Curculionidae: Scolytinae) Tellermanovsky forest field station of the Voronezh region. Forestry Bulletin 22(5): 34-41. doi: 10.18698/2542-1468-2018-5-34-41

Subchev M.A., Toshova T.B., Andreev R.A., Petrova V.D., Maneva V.D., Spasova T.S., Marinova N.T., Minkov P.M. \& Velchev D.I., 2011, Employing floral baited traps for detection and seasonal monitoring of Tropinota (Epicometis) hirta (Poda) (Coleoptera: Cetoniidae) in Bulgaria. Acta Zoologica Bulgarica 63 (3): 269-276.

Sverdrup-Thygeson A., Ims R.A., 2002, The effect of forest clearcutting in Norway on the community of saproxylic beetles on aspen. Biological Conservation 106(3): 347-357. doi:10.1016/S0006-3207(01)00261-0

Tauzin P., 2006, Ethologie et chorologie de Protaetia (Liocola) lugubris Herbst, 1786 sur le territoire français (Coleoptera, Cetoniidae, Cetoniinae, Cetoniini). Cetoniimania 3(1-2): 4-38.

Tomaszewska W., Egorov L.V., Ruchin A.B. \& Vlasov D.V., 2018, First record of Clemmus troglodytes (Coleoptera: Coccinelloidea, Anamorphidae) for the fauna of Russia. Nature Conservation Research 3(3): 103-105. doi: 10.24189/ncr.2018.016

Trushitsyna O.S., Matalin A.V. \& Makarov K.V., 2016, Long-term dynamics and spatial distribution of stable and labile components in ground beetle communities (Coleoptera: Carabidae) in a mosaic of flood-plain meadows. Periodicum Biologorum 118(3): 255-272. doi: 10.18054/pb.2016.118.3.3928

Urban P. \& Schulze W., 2017, Ein aktueller Nachweis des Marmorierten Rosenkäfers Protaetia marmorata (Fabricius, 1792) in der Senne (Nordrhein-Westfalen) (Mitteilungen zur Insektenfauna Westfalens XXII). Mitteilungen der Arbeitsgemeinschaft westfälischer Entomologen 33(1): 15-19.

Visser M.E., Caro S.P., van Oers K., Schaper S.V. \& Helm B., 2010, Phenology, seasonal timing and circannual rhythms: towards a unified framework. Philos. Trans. R. Soc. Lond. 365: 3113-3127. doi: 10.1098/rstb.2010.0111

Vlasov D.V. \& Nikitsky N.B., 2015, Sap beetles (Coleoptera, Cucujoidea, Nitidulidae) of Yaroslavskaya Oblast': subfamilies Carpophilinae, Cryptarchinae and Nitidulinae, together with new records of species from the other beetle families. Euroasian Entomological Journal 14(3): 276-284 (in Russian).

Zamotajlov A.S., Serdyuk V.Yu., Khomitskiy E.E. \& Belyi A.I., 2019, New data on distribution and biology of some rare ground beetles (Coleoptera, Carabidae) in South Russia. Nature Conservation Research 4(4): 81-90 (in Russian). https://dx.doi.org/10.24189/ncr.2019.066 